\title{
CUBES AND CONCEPTS: NOTES ON POSSIBLE RELATIONS BETWEEN MINIMAL ART AND ARCHITECTURE
}

\author{
Claus Peder Pedersen \\ The Aarhus School of Architecture, Nørreport 20, 8000 Århus C, Denmark \\ E-mail: claus.peder.pedersen@aarch.dk
}

Submitted 10 Dec. 2010

\begin{abstract}
The article discusses the links and interchanges between art and architecture in the late sixties and early seventies with emphasis on the exchanges between conceptual or minimal art and architecture. The basic assumption of the article is that the rigorous conceptualisation that characterised minimal artist was transferred into some advanced architectural practices during the late sixties and early seventies. The text examines relations and differences between artists (mainly Sol Lewitt) and architects (mainly Peter Eisenman) and argues that this discussion is still relevant to current practices exploring the potentials of digital based design through the use of parametrics, scripting etc. The text concludes with an example of design-based research conducted by the author, which reflects on the themes raised in the article.
\end{abstract}

Keywords: minimal art, Sol Lewitt, Peter Eisenman, digital design, research through design, architectural theory.

\begin{abstract}
I will refer to the kind of art in which I am involved as conceptual art. In conceptual art the idea or concept is the most important aspect of the work. When an artist uses a conceptual form of art, it means that all of the planning and decisions are made beforehand and the execution is a perfunctory affair. The idea becomes a machine that makes the art. This kind of art is not theoretical or illustrative of theories; it is intuitive, it is involved with all types of mental processes and it is purposeless. It is usually free from the dependence on the skill of the artist as a craftsman. It is the objective of the artist who is concerned with conceptual art to make his work mentally interesting to the spectator, and therefore usually he would want it to become emotionally dry.
\end{abstract}

Paragraphs on Conceptual Art, Sol Lewitt, Artforum, Juni 1967

This article takes its starting point in a discussion of the links and interchanges between art and architecture in the late sixties and early seventies. More specifically it focuses on the exchanges between conceptual or minimal art and architecture. During this period we find a particular fruitful exchange of ideas between artist and architects that is still relevant to current aesthetic thinking. The focus here is mainly on the architectural consequences and potentials of these exchanges ${ }^{1}$. It is possible to argue that an unbroken

\footnotetext{
1 A similar investigation of an artistic lineage might lead to fo-
} cus on artists such as Felix Gonzales-Torres, Mona Hatoum, lineage of architectural thinking and designing runs right up to today. A number of current architectural practices that explores digitally based working methods seems to face some of the same conceptual and aesthetic challenges that conceptual artist such as for instance Sol Lewitt was exploring. The article will attempt to point out some of the still active and relevant questions. The aim of this investigation is not only to give an accurate account of a historically situated set of

Allan McCollum, Rachel Whitehead, Olafur Eliasson etc. See Schmidt, U. Minimalismens æstetik. København: Museum Tusculanums Forlag; Københavns Universitet, 2007. 
ideas. It is just as much a starting point for an artistic development work that is fuelled by the investigations. This work is briefly presented at the end of the article. It is not to be seen as a solution or a conclusion to the questions that is raised during the article. The aim is rather to suggest an approach to architectural research that includes academic as well as design based research without one part being seen as a justification for the other, but hopefully rather instigates a productive gap between the two.

Ulrik Schmidt has described the characteristics of minimal art as 'Objectivity, non-illusionism and reality, an abstract-concrete appearance as well as nonexpressionism and non-anthropomorphism' using 'principles of unity and uniformity, non-relationalism, instrumentalisation and, more profoundly, repetition'. Schmidt traces a desubjectivation in minimalist art. He describes an approach to the work of art where the artist withdraws from directly influencing the work of art, creating, as Lewitt states it, a situation where 'all of the planning and decisions are made beforehand and the execution is a perfunctory affair'. Through much modernist thinking runs an interest in objectivisation. Minimal art could be seen as the logic - and extreme conclusion of some of modernisms basic assumptions, as well as an inherent criticism of these assumptions. ${ }^{3}$ To a certain extent one might claim that this separation of conceptualisation and execution is how architects have been working at least since the academisation of architecture in the renaissance, when architects became detached from the directly involvement in the realisation of the works they designed. Obviously the minimal arts movement investigates the consequences of this separation of conception and execution much further than the average architect, but it might still be one of the reasons for the prolific transfer of ideas from minimal art to architecture. Another reason

\footnotetext{
2 Do. P. 256-257. Author's translation.

3 That might at least seem to be the situation for architects inspired by this movement. See for instance Eisenman, P. Editor's Introduction. The Houses of Memory: The texts of Analogy, in Rossi, A. The architecture of the City. Cambridge, Mass. MIT Press, 1982. p. 4. "The perceived failure of modern architecture to realize this utopia - either to supersede the nineteenth-century city or to mitigate its destruction after the bombings of the Second World War - became the primary condition confronting the architects of a generation which matured in the early 1960s. Their disillusionment and anger were in direct proportion to modern architecture's failure, as much with its unrealized aspirations - its castle of purity - as with their own sense of loss and the impossibility of return; these feelings were directed at the heroic fathers of modern architecture, both for having been and also for having failed. For Rossi's generation it was no longer possible to be a hero, no longer possible to be an idealist; the potential for such memories and fantasies had been taken away forever".
}

could be that the formality and use of geometry that one find in the practices of artist such as Sol Lewitt or Robert Morris might have certain affinities to architecture. In any case there seems to be a parallel interest in conceptually articulated, systematic manipulations of form of these artists and the architectural designs of Peter Eisenman and likeminded architects such as John Hejduk, Michael Graves and Richard Meier during the late sixties and early seventies. There are for instance obvious common traits between Lewitt's art and Eisenman's architecture (Werner Petersen 1990: 19).

Lewitts drawings and sculptures are generated through rule based, straightforward transformations of simple geometrical figures. The series of transformed figures are systematically organised in matrixes that conclusively describes all the possible combinations of the operations. In this way the works of Lewitt seems to explore a dilemma between the transparent logic of the formal operations and the apparent purposelessness of the result. Everything about the process is explained and understandable and yet the result seems to be without inherent meaning, at least if meaning is understood as a specific insight or sensibility expressed through the work.

Something similar characterises Peter Eisenmans early projects. They are perhaps less abstract, as they are based on a recognisable modernistic vocabulary utilising the formal analyses Eisenman made of modernist architects such as Terragni (Eisenman 2003). But the complex decomposition of Eisenman basically explores a similar and deliberate lack of inherent meaning, even though the projects are at once paraphrasing, praising and mocking their modernist heritage.

It seems to be an important point that the processes and transformational logic is readable in the work. In Sol Lewitt's 'Variations of incomplete open cubes' from 1974 , every possible combination of the open cube is constructed and presented in a comprehensive scheme that makes it possible for anyone who would care to check, that all variations are present. This inclusive logic, where every possible variation of a finite series of possibilities is present without differentiation, is a way to eliminate any form of subjective choice or design decision from the realised work.

One finds a similar logic in Eisenman's early architecture. 'House II' from 1969-70 uses a nine-square grid that allows for a highly systematised series of transformations and superimpositions of columns, walls and volumes within the grid. Eisenman's design process is obviously more complex than Lewitt's. In Lewitt's art pieces the ordering principle is mostly immediately readable. It points didactically to the logic that has constructed the piece. Eisenmans process is 
more convoluted and probably only directly traceable by referring to the laborious complex drawings that accompany the published project, even though the realised project displays obvious traces of the process. This complexity might be partly relating to the requirements of a habitable structure. But more importantly it is probably related to an exploration of the syntax of architectural space. For Eisenman geometry is not an abstract spatial system. It is already imbedded within an architectural tradition and Eisenman uses the systematic spatial transformations to break down pre-established notions of spatial organisation in architecture. ${ }^{4}$

Sol Lewitt seems to employ a more innocent notion of geometry. In his work geometry seems to be perceived as an abstract system devoid of connotations. It mainly serves as a vehicle that allows general conceptual ideas to enter into physical form. The properties and rules of geometry make it possible to develop and translate general principles. Lewitt's frequent use of cubes might be understood as part of this approach. The orthogonal angles and equal length of the sides of the cube does not refer to an idealised geometry, but is rather considered as a default option uninfluenced by specific conditions or contexts. The white colours and anonymous materials further support this idea, hinting at standardisation and industrialised production. But even if this idea is easily understandable one could question whether Lewitt is successful in completely breaking any connotations and relations. The cubes might after all still refer to previous notions of a relation between ideal geometries and meaningful form - a frequent belief throughout the history of architecture. Even if these connotations are unintended by Lewitt, the vague recognisability might still be an important part of the fascination of his work. ${ }^{5}$

The project that accompanies this article is part of an ongoing research by design project by the author. It could be thought of as a conclusion to the text. In this case it would of course not be understood as a summation of the findings of the paper and putting these findings into perspective of already existing research. It would rather be a conclusion in terms of trying to establish a relation between an analysis of and reflection on an existing body of work and a new work that tries to explore and expand some of the findings of the

\footnotetext{
4 More specifically Eisenman is probably reacting to Colin Rowes famous text The mathematics of the ideal villa that proved similar geometric organisations of Villas by Palladio and Le Corbusier. Rowe, C. The mathematics of the ideal villa, and other essays. 1st ed. Cambridge Mass.: MIT Press, 1982.

5 Donald Judd might be an example of an artist that explored the relation between minimal art and architecture in a more immediate way.
}

analysis. In this way the accompanying project could be considered as a continuous exploration of some of the conceptual and formal questions raised in Lewitt and Eisenman's works. The work is based on a formal exploration of a nine-square grid. This exploration is structured on a combinatory series of objects based on an adapted 'menger sponge' - principle (Fig. 1) ${ }^{6}$. Instead of removing the central cube of each nine square grid in each step as in the original menger sponge, the project removes a different number of cubes in every iteration. This logic can be explored in different ways. Fig. 2 describes a transformative series based on three iterations where the first iteration removes two cubes, the next four and the last one. In this case it is possible to remove four cubes in 12 different ways from the ninesquare grid (with the precondition that the variations are limited to those that are symmetrical along a vertical axis). This produces a series of 12 different cubic objects (Fig. 3) that unfolds the possible variations. This series is then in turn one of a series of the six possible ways the three iterative levels can be combined (1-2-4, $1-4-2,2-1-4,2-4-1,4-1-2$ and $4-2-1)$ resulting in 72 different objects (see Figs. 4-6 for examples).

It is using the didactic approach of Lewitt where the formative logic is immediately accessible and readable. Instead of Peter Eisenman's critical dissection of the formal syntax of modernist architecture or Lewitt's

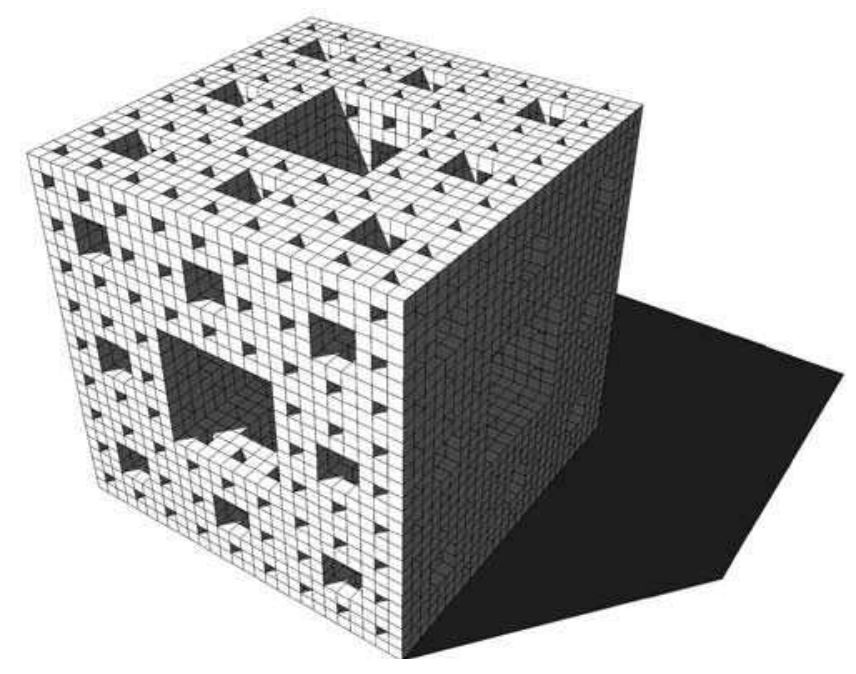

Fig. 1. Construction of a Menger sponge

\footnotetext{
${ }^{6}$ Menger sponge can be constructed as follows: 1 . Begin with a cube. 2. Divide every face of the cube into 9 squares, like a Rubik's Cube. This will sub-divide the cube into 27 smaller cubes. 3. Remove the cube at the middle of every face, and remove the cube in the center, leaving 20 cubes, resembling a Void Cube. This is a level-1 Menger sponge. 4. Repeat steps 1-3 for each of the remaining smaller cubes. Available from Internet: $<$ http://en.wikipedia.org/wiki/Menger_sponge>
} 

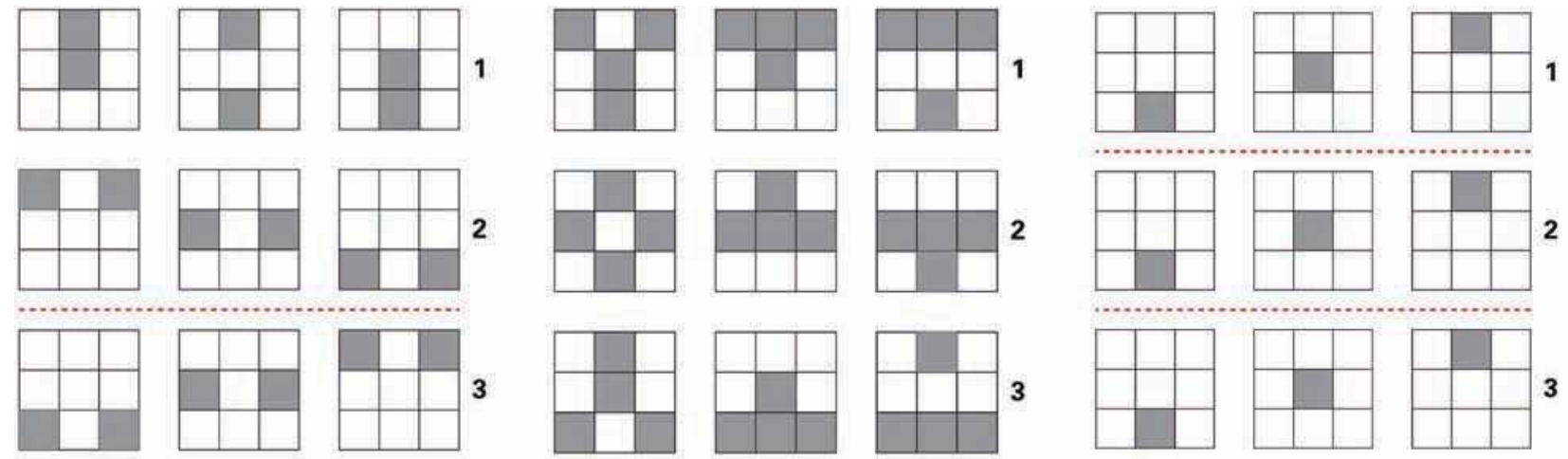

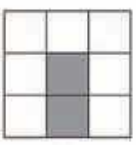

a

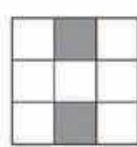

b

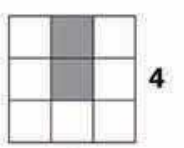

c

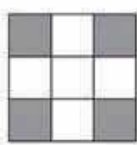

a

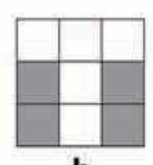

b

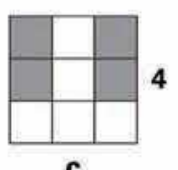

c

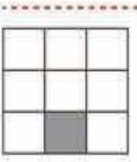

a

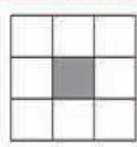

b

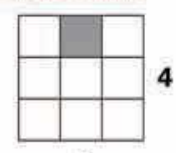

c

Fig. 2. Drawing that describes what cubes should be removed in the three iterations that is part of the $2-4-1$ series
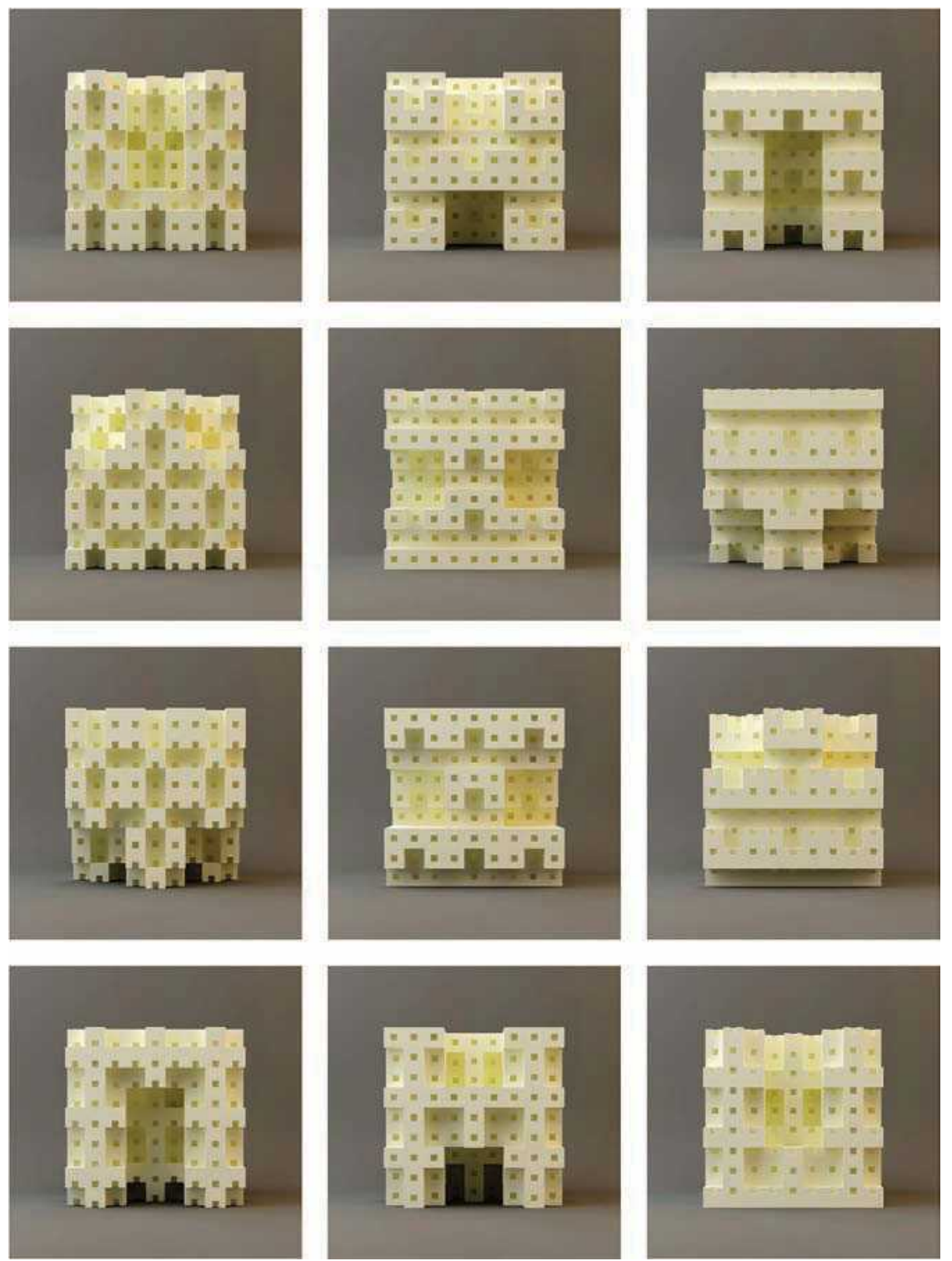

Fig. 3. Complete $2-4-1$ series 


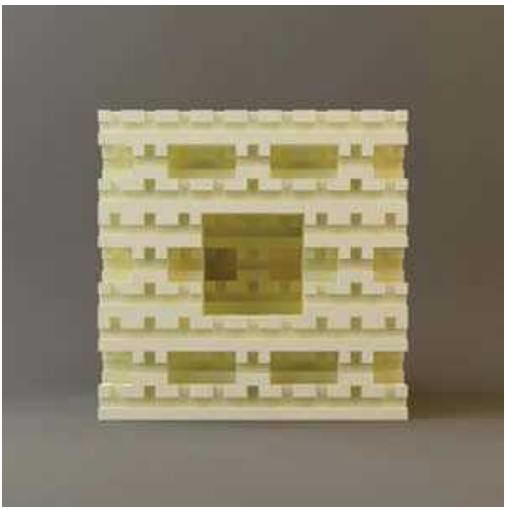

Fig. 4. Object from 1-2-4 series

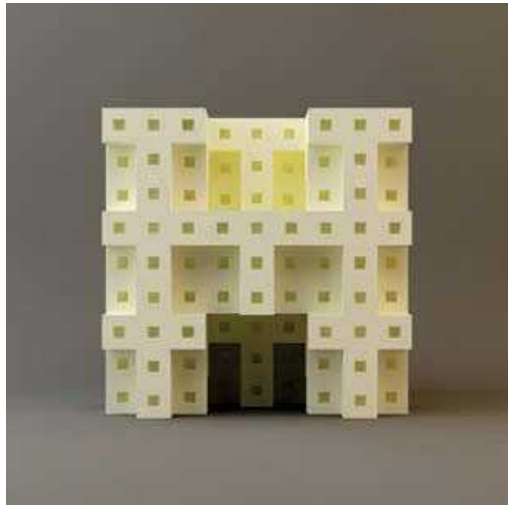

Fig. 5. Object from 2-4-1 series

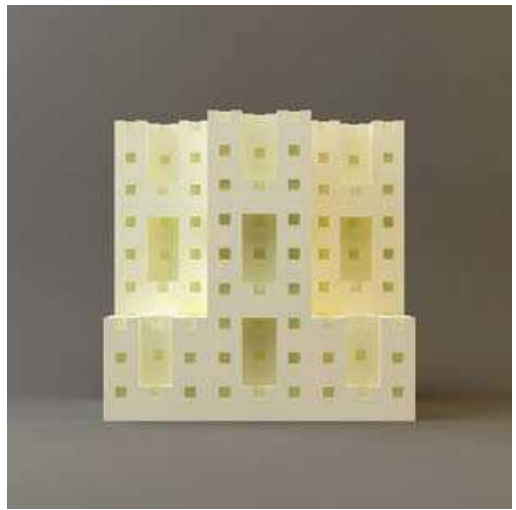

Fig. 6. Object from 4-2-1 series exploration of the concept as artistic motor it attempts to explore the proliferation of formal organisations made possible by systematised processes. The resulting objects are just as purposeless as Lewitt's sculptures. But at the same time the cubic shapes and hierarchically nested geometries hopefully hint at architectural or perhaps rather proto-architectural potentials.

\section{References}

Eisenman, P. 1982. Editor's Introduction. The Houses of Memory: The texts of Analogy, in Rossi Aldo, The architecture of the City. Cambridge, Mass. MIT Press.

Eisenman, P. 2003. Giuseppe Terragni: transformations, decompositions, critiques. New York: Monacelli Press.

Rowe, C. 1982. The mathematics of the ideal villa, and other essays. 1st ed. Cambridge Mass.: MIT Press.

Schmidt, U. 2007. Minimalismens aestetik. København: Museum Tusculanums Forlag; Københavns Universitet.

Werner Petersen, E. 1990. Dekonstruktion af modernismens figur. Copenhagen: Det Kongelige Danske Kunstakademi, Stig Brøgger og Hein Heinsens skoler.

\section{KUBAI IR KONCEPCIJOS: \\ PASTABOS APIE GALIMAS MINIMALIOS SKULPTŪROS IR ARCHITEKTŪROS SĄSAJAS}

\section{P. Pedersen}

Santrauka. Straipsnyje analizuojamos XX a. septintojo dešimtmečio pabaigai ir aštuntojo dešimtmečio pradžiai būdingos kai kurios konceptualizmo ir minimalizmo apraiškos skulptūroje ir architektūroje. Tyrimas remiasi prielaida, kad griežtai konceptualių metodų taikymas iš minimalistinès skulptūros buvo perkeltas ị kai kurias progresyvias architektūrines praktikas. Aptariant sąsajas tarp skulptorių, tokių kaip Sol Lewittas, ir architektų, tokių kaip Peteris Eisenmanas, siekiama atskleisti, kad jų kūryboje plètotos idejos vis dar išlieka aktualios šių dienų meninèje architektūros kūryboje, tiriančioje kompiuterinio projektavimo galimybes, naudojant parametrinị modeliavimą, veiksmus automatizuojantị programavimą (scriptingą). Analizè iliustruojama modeliais, kuriuos autorius per meninị tyrimą sukūrè pritaikęs straipsnyje nagrinètus metodus.
Reikšminiai žodžiai: minimalus menas, Sol Lewitt, Peter Eisenman, kompiuterinis projektavimas, meninis tyrimas, architektūros teorija.

\section{CLAUS PEDER PEDERSEN}

Claus Peder Pedersen is educated as architect from The Royal Danish Academy of Fine Arts, School of Architecture in 1992 and holds a PhD from The Aarhus School of Architecture from 1998. He has been assistant professor at The Aarhus School of Architecture from 1999-2002 and associate professor at The Royal Danish Academy of Fine Arts, School of Architecture 2004-2007 and holds a position as associate professor The Aarhus School of Architecture since 2007 where he currently teaches a studio in digitally based design and acts as head of the research committee. Parallel to his academic career he has been active in practice as partner in the architectural office Transform from 1997-2003 and in the cross-disciplinary practice Blankspace since 2003. His research interests are focused on the conception and initiation of architectural design involving how to use and develop ideas, methods, tools, forms or representation in the architectural design process. This research is especially focused on the use of digital tools. Beside that he has also research experience from the field of urban planning focusing especially on infrastructure. 